\title{
Article \\ Designing Policy Mixes for Resource Efficiency: The Role of Public Acceptability
}

\author{
Martha Bicket * and Robin Vanner \\ Policy Studies Institute, 35 Marylebone Road, London NW1 5LS, UK; r.vanner@psi.org.uk \\ * Correspondence: m.bicket@psi.org.uk; Tel.: +44-20-7911-7534 \\ Academic Editors: Francesca Montevecchi and Martin Hirschnitz-Garbers \\ Received: 7 February 2016; Accepted: 7 April 2016; Published: 13 April 2016
}

\begin{abstract}
Where the public acceptability of a policy can influence its chance of success, it is important to anticipate and mitigate potential concerns. This paper applies search frequency analysis and a form of claims-making analysis to identify public acceptability concerns among fourteen policies proposed by the EU-funded DYNAMIX project to achieve EU resource efficiency. Key points of contention in the corresponding public discourses focus primarily on trust, fairness, effectiveness and cost. We use our findings to provide specific recommendations for the design and implementation of the proposed policy mix which are intended to improve the public acceptability of contentious aspects, and highlight some broader insights for policymakers.
\end{abstract}

Keywords: public acceptability; sustainability transitions; resource efficiency; policy mix; policy sequencing

\section{Introduction}

Public acceptability is increasingly considered to be an important factor in the design of effective policy [1-5]. Acceptability and public support are particularly important concerns for managing transitions to sustainability [6], which forms the context for this paper. Policies for a transition to sustainable resource use will likely involve a significant degree of change in behaviour and practices and will therefore depend to a large extent on the consent and cooperation of actors at various levels, from the individual to the multinational.

Public acceptability is an important concern for multiple reasons. Public buy-in for a given policy or policy objective can improve participation and compliance, reducing enforcement costs and increasing overall effectiveness. Public acceptability plays a key role in political agenda-setting [7-11]. For example, in democratic societies, mainstream public discourse and social movements can steer policy debate and action by giving amenable politicians a democratic mandate, or others, a threat to re-election [12]. Ultimately, public resistance - or fear of it—can obstruct or reverse policy decisions. Examples of policy failures attributed to low public acceptability include: the rejection of a heat-based energy tax (the "BTU" tax) in the USA [13]; the rejection of the 1993 proposal to increase the value added $\operatorname{tax}$ (VAT) on UK domestic energy [14]; the rejection of proposals to tax fossil energy in Switzerland in 2000 and in France in 2010 [15,16]; and the rejection of proposed road-user charges in Edinburgh and Manchester [7,17].

This paper is situated in the broader work of the EU-funded DYNAMIX project, tasked with designing policy mixes for EU resource efficiency. The analysis forms part of a wider ex-ante assessment of the economic, environmental, social, and feasibility implications of the project's proposed policy packages which seek to achieve absolute decoupling - growth without corresponding environmental impact-in the EU by 2050. Findings from the ex-ante analysis, including those reported here, are used to refine and enhance the design and proposed implementation of the final set of recommended policies. 
There is a broad range of overlapping terms and definitions in the literature on public acceptability $[9,15]$. The terms public, social, political, acceptability, acceptance, buy-in, support, opinion and feasibility are used in various combinations and often interchangeably. In this paper, our primary focus is on assessing and improving the public acceptability of policies, where we loosely define public as all individuals who stand to be affected (directly or indirectly) by the given policies in question, as well as additional interested individuals who choose to express an opinion. Social (defined here as encompassing all agents involved, including organisations) and political acceptability and feasibility are not the primary focus in this paper, but we include them if and when they influence public acceptability. For example, we consider the acceptability of organisations when relevant through their lobbying of the public via the media and involvement in public debate. However, the distinction is not clear-cut; it is not possible to entirely disentangle the public from organisations, policymakers, government, political parties, media or lobbies, since the latter are simply organised groupings of individuals who are themselves members of the public. Public acceptability is therefore described and influenced by a complex system of interactions on multiple levels.

In this introduction, we draw on notable recent attempts in the literature to identify the multiple processes influencing public acceptability (for detailed overviews, see $[8,15]$ ) in order to summarise key factors influencing public acceptability and outline current thinking on how to improve it.

People are more likely to accept policy if they trust the governing institution $[8,14,15,18,19]$, while a lack of trust has been observed to be accompanied by lower levels of willingness-to-pay [20]. The relationship between trust and public acceptability has at least two components: one is confidence in an institution's choice of policy design and capability to implement it effectively. Policies that are perceived to be effective have higher public acceptability [8,15]. For example, a group of individuals in Norway were shown to be more likely to support a fuel tax if they believed that it would have the desired effect on behaviour and climate change [21]. In addition, strong public distrust about the effectiveness of a road-user charge in Edinburgh coincided with its referendum failing to reach a majority of support [17]. A second trust concern is whether the institution's motives are transparent; policies that are perceived to have ulterior motives have lower public acceptability. This is particularly the case with instruments that seek to levy a tax, which can be perceived by both the public and businesses simply as a means to generate additional revenue [14].

The perceived personal cost of a policy, including its impact on financial welfare, wellbeing, behaviour and freedom of choice, is widely observed to negatively impact acceptability $[7,8,15,22]$. Correspondingly, there is usually a clear preference in terms of public acceptability for "carrot" $v s$. "stick" measures. However, the latter can still have high acceptability if their perceived effectiveness is also high [7].

The extent to which a policy is perceived to be fair also appears to be a key factor influencing public acceptability. Perceived distributional fairness of costs and environmental burdens [14,15], and procedural fairness [8] are linked to higher public acceptability. In one study, the effect was shown to be a stronger predictor of support for a policy than personal cost [21].

Cherry et al. [1] and Munaretto and Walz [9] highlight the role of limits to rationality and cognitive constraints as influences of public acceptability. For example, people tend to have an inherent bias for the current situation (status quo bias). Additionally, people may over- or underestimate the costs associated with a policy [23].

Individuals are more likely to accept climate change policies if they are aware of the consequences of climate change and the benefits are well described [15], pointing to the influence that addressing information deficit may have on public acceptability. However, supplementary information on its own does not necessarily improve support [21].

Ironically, perceived public acceptability, especially the perception of controversy, is itself also a key factor in the public acceptability of a policy; people are less likely to support a policy if they expect others to defect [7]. A strong social norm, where attitudes and behaviour in support of the policy are common knowledge, is associated with higher public acceptability [24]. 
The media can have a profound yet unpredictable impact on public opinion and therefore on public acceptability. This influence can be intentional or unintentional. The repetition and prominence of messages in the media strongly inform the salient issues in an individual's mind at any given moment of opinion-formation or decision-making [25]. Through a motivation to stimulate debate, information and opinions expressed in the media have a tendency to counter rather than reinforce knowledge, which can lead to highly visible minority viewpoints [2]. Furthermore, even subtle differences in terminology used to present information can have significant effects on opinion and behaviour; a large body of literature in the field of communications science explores the impacts of these "media effects" (see [25]).

Exogenous events such as economic crises and extreme weather events also influence public opinion and acceptability of policies positively or negatively, depending on the issue $[9,26,27]$. Part of their influence is due to the salience that events give to certain issues over others $[8,28]$. Differences in the UK's and Germany's levels of public acceptability of nuclear power in response to the Fukushima disaster illustrate that the impact of high-profile events on public acceptability can vary significantly by country [29].

A crucial issue when it comes to the formation of opinion and influencing public acceptability is that new information and salient issues are not simply processed and added to the "mental heap". Instead, individuals tend to test new information against a framework of their own existing knowledge, values and beliefs [30]. Individuals then accept, reject or adapt the new information and/or their views [31]. We call this framework the individual's personal "paradigm" or worldview (see [32]). Using value-belief-norm theory [33], environmental beliefs, personal values and norms have been shown to predict the public acceptability of certain environmental policies [34].

These influencing factors present corresponding insights into how the public acceptability of a policy might be improved. Changing the policy design can improve public acceptability, for example by using "carrot" rather than "stick" measures [7] and, if using a tax, by earmarking revenues [35,36]. Experiments suggest that providing transparency over social norms and how other individuals behave may improve acceptability [7] and participation (e.g., reusing hotel towels [37]), while tailoring the framing and choice of words used to describe a policy can also improve support [38-41]. Addressing the information deficit is more challenging; simply giving more information to an individual is suggested to have a limited effect on improving his or her acceptance [42], however, efforts to improve media literacy may prove more successful [2]. Further suggestions for how to improve public acceptability similarly promote more participatory and less passive approaches; evidence suggests that involving the public in the deliberation and design of policy $[8,43-45]$, and trials $[1,18]$ have strong potential to improve public acceptability.

However, while these provide policymakers with a range of promising tools, there is no silver bullet for guaranteeing the public acceptability of a policy. The system of interactions that determine public acceptability at any given moment is complex and dynamic. Indeed, public acceptability for a given policy may change in any number of ways over time (e.g., the Stockholm congestion charge, whose support grew from 30 to 70 percent of the population [8]). This dynamic nature of public acceptability presents opportunities as well as challenges; contextual conditions such as the political climate, social norms, exogenous events and salient issues can align to create windows of opportunity-key moments where a policy's acceptability and potential of success are particularly high [46,47].

It is against this considerable background that our paper seeks to contribute to the development of successful policy tools and practices for sustainability through a better understanding of the public acceptability of a set of promising policies. In particular, our work responds to an important gap in the field (see [8]) by exploring the acceptability of combinations of policies (or policy mixes) for sustainability. We ex-ante analyse the public acceptability of a mix of policies proposed by the EU-funded DYNAMIX project; our aim is to identify potential acceptability issues and to propose adjustments to the policy mix to overcome these and enhance the policies' effectiveness. The proposed policies on which we 
conduct our analysis are fully described in [48]. In this paper, we report on our key findings from a subset of them. Briefly, they include:

- Six policies which concern taxes:

Green fiscal reform: internalisation of external environmental costs

Green fiscal reform: materials tax

A VAT on meat products

A "circular economy tax trio" on the extraction of selected virgin materials, and landfilled and incinerated waste

Reduced VAT for the most environmentally advantageous products and services

- EU-wide introduction of feebate schemes for selected products categories

- Six alternative (non-tax) behaviour change policies:

$\bigcirc \quad$ Enabling a shift from consumption to leisure

Stimulation of sharing systems

Local currencies for labour-based services

Step-by-step restriction of advertising and marketing

$\bigcirc \quad$ Targeted information campaign on changing diets and on food waste

- Development of food redistribution programmes/food donation to reduce food waste

- Two producer-focus policies:

Product standards

Boosting extended producer responsibility

We use our findings to propose specific and broader recommendations to policymakers for how to improve the public acceptability, and consequently the effectiveness, of policies for sustainability in the EU.

\section{Materials and Methods}

\subsection{Methods for Assessing Public Acceptability}

Several studies have sought to measure the public acceptability of environmental polices $[3,21,49,50]$. The majority of studies use stated preference methods (e.g., opinion polling, choice experiments, and the "New Environmental Paradigm" scale [51]). Stated preference methods are popularly used when exploring hypothetical situations for which there is no real-world data, and are therefore particularly relevant to the assessment of the ex-ante public acceptability of policies that have not yet been implemented. Ford et al. [3], for example, ask participants to rate the acceptability of proposed forest management policy options on a 7-point Likert scale. In another study, researchers use survey-based conjoint choice experiments to identify factors affecting acceptability and use the results to estimate willingness-to-pay as a proxy for the acceptability of different policy mixes for greenhouse gas mitigation (see [15]). Conversely, studies that seek to evaluate public acceptability based on real-world revealed behaviour are less common; in a systematic review of climate policy public acceptability studies since 2000, the only studies found to use real-world behaviour are those analysing referenda votes (e.g., [52]), and are exclusively focused on Switzerland [15].

As opposed to preferences as revealed in real-world choices and behaviour, stated preferences are largely subject to the biases of the collection methods, namely surveys, used to elicit them. Bias may arise from measurement errors including interviewer bias, framing effects due to question ordering and wording (e.g., [53]), response bias, and the (disputed) Hawthorne effect, under which subjects may perform differently because they know they are under observation (see [54]). Bias may also arise from 
sampling errors such as selection bias and non-response bias, leading to results that are not accurately representative of the population of interest.

Following dramatic changes in modes of sharing and access to data over the past two decades as a result of the Internet and other technological advances, new methods and forms of data present a range of promising improvements and alternatives to traditional survey methods for public opinion research [55]. Our method in this paper seeks to explore and exploit some of these new opportunities.

\subsection{Assessing Public Acceptability in DYNAMIX}

The proposed DYNAMIX policy mix seeks to contribute to EU resource efficiency, therefore our study faces the challenge of assessing acceptability across the challenging scope of the 28 current Member States of the European Union. Given the weaknesses associated with stated preference methods such as opinion polling used to describe public opinion (see also [12,56-59]), as well as the practical benefits associated with the availability and abundance of online data, in this study we take a revealed preferences-type approach to evaluating public acceptability.

Our method has two core components. First, we conduct an analysis of online search frequencies using culturally-appropriate terminology to highlight the Member State populations where keywords may have particularly high salience. Second, we conduct an in-depth analysis of the visible public discourse using media articles and supplementary sources in the online public domain, identifying key discourses and their influence. Based on our findings, we suggest modifications and enhancements to the content, design and/or implementation of the DYNAMIX policy mix which aim to improve public acceptability and mitigate low assessments of likely acceptability.

\subsubsection{Search Frequency Analysis}

We use data from the online search frequency analysis tool Google Trends [60] to compare the relative popularity of key Internet search terms in the EU by geographical location and date. A small but growing body of literature highlights the potential of Google Trends as a research tool, e.g., for the "identification of broad socio-political trends" [61], with examples of correlations found between relevant online search frequencies and real effects such as increased media coverage of the issue as well as with economic indicators such as unemployment, travel and consumer purchases [62,63]. Google Trends results are normalised to place an emphasis on relative popularity of search terms, which reduces sample bias that might otherwise arise due to varying population sizes, and they also disregard duplicate searches.

A crucial preliminary step in this stage of our analysis is the identification of key terms for each of the policies of interest. Terms are chosen with reference to the detailed descriptions for each of the proposed DYNAMIX policies (in [48]), and are selected based on their simplicity and representativeness of each policy's defining focus and/or characteristics. For example, key terms for the proposed policy "Development of food redistribution programmes to reduce food waste" include "food waste" and "food banks". Additionally, other terms such as "Good Samaritan law", which features prominently in past UK discourse on proposed food redistribution policy and programmes (e.g., [64]) are added as we identify and refine key terms during later stages of the analysis to ensure as far as possible that the terminology is culturally-appropriate and reflects conventions used by populations of interest. The key terms are translated into the EU official languages and refined using EUR-Lex [65], a repository of official EU documents including regulations, legislative proposals and reports, which provides a high-quality source of culturally-appropriate translations for the key terms. Using Google Trends, we then explore the populations in which the identified key terms are more commonly used in online searches and use this as a proxy for the salience of those issues relative to other issues among those populations. 


\subsubsection{Discourse Analysis}

We follow up our search frequency analysis with a more in-depth analysis of relevant visible public discourses, in which we seek to identify and explore prominent acceptability concerns for the DYNAMIX policy mix, including key areas and sources of contention, and to give a qualitative assessment of their potential strength or severity.

Our approach is influenced by Statham and Tumber [66] who use publicly visible media discourse as a proxy to assess the political climate of a country with regard to specific issues. Using claims-making analysis (also known as "political claims analysis"; see [67]), Statham and Tumber rely on the dual role of media with respect to public opinion: first, that the media act as a filter for identifying salient information, selecting and reporting what they deem to be the most newsworthy events and claims at a given point in time; and second, that the media is also a key conduit through which individuals are exposed to information, and as such it sets the agenda regarding what information becomes salient to the public [66]. The media is therefore a good record of some of the more salient issues and corresponding positions of certain actors at a given point, as well as a record of the information, claims and influences to which the public have likely been exposed.

We select online-accessible, publicly-available written media outputs such as newspaper articles as our primary source of data. Where relevant we also supplement this with published publicly-accessible government statements, reports and consultations. We use claims-making analysis and the key terms identified in the previous stage to find and record claims and corresponding relevant information about the source, framing, actors, and key events. We code the perceived advantages and disadvantages in the discourse against a range of concern categories informed by the literature: (perceived) effectiveness, motive, cost, fairness, social norm and cultural implications, and note whether the dominant framing of the discourse in each of these categories is aligned with higher or lower levels of public acceptability.

Based on the extent, prominence and framing of the concerns among the visible discourse analysed, we provide a qualitative assessment of the likely public acceptability of the policy on a 5-point scale based on whether, in its current form, attempted implementation of the policy within a democratic system would likely be: unnoticed, uncontentious, contentious, highly contentious or unimplementable. The descriptive criteria for these assessments are outlined in Table 1. Where significant public acceptability concerns are identified, we propose corresponding modifications to the design and/or implementation of the DYNAMIX policies.

Table 1. Descriptive criteria used in the qualitative assessment of overall public acceptability of policies in the DYNAMIX policy mix.

\begin{tabular}{cl}
\hline $\begin{array}{c}\text { Acceptability } \\
\text { Assessment }\end{array}$ & \multicolumn{1}{c}{ Descriptive Criteria } \\
\hline Unnoticed & $\begin{array}{l}\text { The policy measure would likely be proposed and implemented without significant public } \\
\text { attention or concern. }\end{array}$ \\
\hline Uncontentious & $\begin{array}{l}\text { While aspects of the policy measure may stimulate some degree of concern among } \\
\text { minority public groups, it is unlikely that any formal coalition of disparate stakeholders } \\
\text { would form to oppose it. }\end{array}$ \\
\hline Contentious & $\begin{array}{l}\text { Proposal of the policy measure may likely cause considerable public concern on the issues } \\
\text { raised, leading to the formation of coalitions of disparate stakeholders to oppose it. } \\
\text { Implementation of the policy measure in its current form will likely require the investment } \\
\text { of political capital from the governing body. }\end{array}$ \\
\hline contentious & $\begin{array}{l}\text { Proposal of the policy measure may very likely cause considerable public concern on the } \\
\text { issues raised, leading to the formation of coalitions of disparate stakeholders to oppose it. } \\
\text { Implementation of the policy measure in its current form will likely require the investment } \\
\text { of considerable political capital from the governing body and favourable political and } \\
\text { economic conditions. }\end{array}$ \\
\hline Unimplementable & $\begin{array}{l}\text { Proposal of the policy measure may very likely cause considerable and negative concern } \\
\text { on the issues leading to the formation of coalitions of disparate stakeholders to oppose it. } \\
\text { It is unlikely that the policy measure could be implemented in its current form. }\end{array}$ \\
\hline
\end{tabular}




\subsection{Limitations and Caveats}

The use of search frequency analysis methods such as Google Trends is relatively new and more work is needed to explore their value and limitations as a research tool in general, as well as for measuring issue salience in particular. Other legitimate concerns focus on how Internet access and use-behaviour may differ between different socio-economic groups and cultures $[55,68]$. Without accompanying socio-economic data we also cannot draw watertight conclusions about the representativeness of our sample at Member State or EU level or the likely degree of bias.

Although we recognise the strengths of using the media as a key source for our analysis based on its dual role in both filtering and fixing salient issues in the public discourse, the media articles identified in our analysis may not fully and accurately reflect the attitudes of the public. For example, headlines may be intentionally provocative, and the readers may know (and be expected) not to take them at face-value. The analysis also only picks up on the visible discourse, and misses out on the indirect impact on public acceptability of closed-door lobbying of government by business, for example.

Similarly, a lack of data cannot be relied upon to infer public acceptability or low public interest in an issue. For example, strong regional or national views on an issue may remain undiscussed because they are widely held as common knowledge, or the issues may not yet have entered the public discourse, but nonetheless might rally strong opinion if they were to.

Various challenges arise from the broad cross-national and cross-cultural nature of our research. In particular, the analysis relies to a large extent on our selection of search terms and understanding of media articles, and as such is susceptible to bias from mistranslation and/or misinterpretation. Terms used interchangeably in one population may evoke different meanings in another (e.g., [69]).

Finally, there are more fundamental challenges associated with attempting to measure public opinion and how it might change in response to policies implemented in the future. The multiple and interacting factors touched upon in the introduction to this paper highlight this complex nature of public acceptability.

These are important considerations to keep in mind when interpreting the results. Here we do not seek to calculate a representative measurement of public opinion; instead, our analysis aims to provide qualitative insights into potential acceptability issues of the policies in question.

\section{Results}

We summarise the key highlight results from our analysis in Table 2, and provide further in-depth findings below.

Table 2. Summary findings.

\begin{tabular}{|c|c|c|c|}
\hline $\begin{array}{l}\text { Proposed DYNAMIX } \\
\text { Policy }{ }^{1}\end{array}$ & $\begin{array}{l}\text { Key Terms and Member } \\
\text { State Hotspots }{ }^{2}\end{array}$ & Concern Categories $^{3}$ & Acceptability \\
\hline $\begin{array}{l}\text { Green fiscal reform: } \\
\text { internalisation of } \\
\text { environmental costs }\end{array}$ & \multirow{4}{*}{$\begin{array}{l}\text { "Green taxes" } \\
\text { DK, UK }\end{array}$} & \multirow{3}{*}{$\begin{array}{l}\text { effectiveness }(-) \\
\text { motive }(-) \\
\text { cost }(-) \\
\text { fairness }(-) \\
\text { cultural }(-)\end{array}$} & highly contentious \\
\hline $\begin{array}{l}\text { Green fiscal reform: } \\
\text { materials tax }\end{array}$ & & & highly contentious \\
\hline $\begin{array}{l}\text { Circular economy tax } \\
\text { trio on extraction, } \\
\text { landfill and incineration } \\
\text { of virgin materials }\end{array}$ & & & highly contentious \\
\hline $\begin{array}{l}\text { Reduced VAT for } \\
\text { environmentally } \\
\text { advantageous products } \\
\text { and services }\end{array}$ & & $\begin{array}{l}\text { effectiveness }(-) \\
\text { cost }(+) \\
\text { fairness }(-)\end{array}$ & uncontentious \\
\hline
\end{tabular}


Table 2. Cont.

\begin{tabular}{|c|c|c|c|}
\hline $\begin{array}{l}\text { Proposed DYNAMIX } \\
\text { Policy } 1\end{array}$ & $\begin{array}{l}\text { Key Terms and Member } \\
\text { State Hotspots }{ }^{2}\end{array}$ & Concern Categories $^{3}$ & Acceptability \\
\hline VAT on meat products & $\begin{array}{l}\text { "Meat consumption" } \\
\text { ES, UK, FR, PL, PT, RO, SE } \\
\text { "Meat tax" } \\
\text { (same as "meat consumption") }\end{array}$ & $\begin{array}{l}\text { effectiveness }(-) \\
\text { motive }(-) \\
\text { cost }(-) \\
\text { fairness }(-)\end{array}$ & highly contentious \\
\hline $\begin{array}{l}\text { EU-wide feebate } \\
\text { schemes for select } \\
\text { products categories }\end{array}$ & $\begin{array}{l}\text { "Feebate" /“Smart } \\
\text { taxes" / "Bonus Malus" } \\
\text { DE, AT, FR, BE, IT, LV, HU, NL } \\
\text { BE, PL, RO }\end{array}$ & $\begin{array}{l}\text { cost }(+,-) \\
\text { fairness }(-)\end{array}$ & uncontentious \\
\hline $\begin{array}{l}\text { Shift from consumption } \\
\text { to leisure }\end{array}$ & $\begin{array}{l}\text { “Working Time Directive" } \\
\text { DE, UK, IE } \\
\text { “working time" } \\
\text { ES, DK, DE, EL, FR, UK, IE, LV, } \\
\text { LT, HU, NL, PL, PT, RO, SK, } \\
\text { SL, FI, AT, BE } \\
\text { "Paid annual leave" } \\
\text { BG, UK, HU, FI, FR } \\
\text { "part time" / "part time work" } \\
\text { BE, AT, SE, FI, NL, HU, IT, FR, } \\
\text { DE, CZ, ES, BG }\end{array}$ & $\begin{array}{l}\text { effectiveness }(-) \\
\text { cost }(+,-)\end{array}$ & highly contentious \\
\hline $\begin{array}{l}\text { Restrictions on } \\
\text { advertising and } \\
\text { marketing }\end{array}$ & $\begin{array}{l}\text { "Misleading advertising" } \\
\text { ES, DE, UK, FR, NL, PT }\end{array}$ & $\begin{array}{l}\text { effectiveness }(-) \\
\text { cost }(-) \\
\text { fairness }(-) \\
\text { cultural }(+)\end{array}$ & contentious \\
\hline $\begin{array}{l}\text { Local currencies for } \\
\text { labour-based services }\end{array}$ & $\begin{array}{l}\text { “LETS" } \\
\text { IT, AT, SE, DE, BE, ES, NL, UK, } \\
\text { PL, FR }\end{array}$ & $\begin{array}{l}\text { effectiveness }(-) \\
\text { cost }(-)\end{array}$ & uncontentious \\
\hline $\begin{array}{l}\text { Information campaign } \\
\text { on food waste and } \\
\text { changing diets }\end{array}$ & $\begin{array}{l}\text { "Food waste" } \\
\text { UK, IT, NL, SE }\end{array}$ & $\begin{array}{l}\text { effectiveness }(+,-) \\
\text { social norm }(+)\end{array}$ & unnoticed \\
\hline $\begin{array}{l}\text { Redistribution } \\
\text { programmes to reduce } \\
\text { food waste }\end{array}$ & $\begin{array}{l}\text { "Food waste", as above } \\
\text { "Food banks" } \\
\text { FR, UK, ES, BE, NL, PL } \\
\text { "Good Samaritan law" UK }\end{array}$ & $\begin{array}{l}\text { effectiveness }(+,-) \\
\text { fairness }(+) \\
\text { social norm }(+)\end{array}$ & uncontentious \\
\hline $\begin{array}{l}\text { Stimulation of sharing } \\
\text { systems }\end{array}$ & $\begin{array}{l}\text { "Car-sharing" / "carpooling" } \\
\text { DE, FR, AT, IT } \\
\text { "Renting" } \\
\text { ES, UK, IT, NL, IE }\end{array}$ & $\begin{array}{l}\text { effectiveness }(-) \\
\text { cost }(+) \\
\text { fairness }(+)\end{array}$ & uncontentious \\
\hline Product standards & & $\begin{array}{l}\text { effectiveness }(-) \\
\text { fairness }(-)\end{array}$ & highly contentious \\
\hline $\begin{array}{l}\text { Extended producer } \\
\text { responsibility }\end{array}$ & NL, UK, FI & effectiveness $(-)$ & highly contentious \\
\hline
\end{tabular}

${ }^{1}$ The proposed DYNAMIX policies listed here are detailed further in [48]. ${ }^{2}$ Member States with high relative search frequencies for the corresponding keywords (English keywords provided for reference). ${ }^{3}$ Common concern categories identified in the corresponding public discourses, and their likely impact on public acceptability: positive $(+)$ or negative $(-)$.

In our analysis we group together policies with significant conceptual overlap and potential to provoke similar concerns in public discourse, for example, grouping together a number of the proposals prominently featuring a tax that are commonly represented by a common theme in the public discourse around "green taxes". For each of the policies, we indicate whether the dominant framing of the discourse in the concern categories observed may be associated with higher $(+)$ or lower $(-)$ levels of public acceptability.

Of the fourteen policies assessed here ex-ante for their public acceptability, we have found seven to be potentially highly contentious. We highlight the key public acceptability concerns observed in our 
analysis of the relevant discourses below. These are presented under three broader categories: policies prominently featuring a tax; alternative (non-tax) policies seeking to stimulate broader behaviour change; and other policies with a strong focus on producers.

\subsection{Discourse Themes on Tax Policies}

Our analysis of visible discourses around "green taxes" reveals potential for considerable public acceptability issues for three of the proposed DYNAMIX policies: two concerning green fiscal reform-one internalising environmental costs and the other a materials tax-and the proposed tax "trio" on extraction, landfilling and incineration of virgin materials. We found frequent appeals in the public discourse to concerns over the fairness, cost and effectiveness of green taxes. Indirect concerns were also raised about motive (and therefore trust) through debate around how tax revenues are, will, and should be used. Fairness concerns focus on potential regressivity of a tax and its impact on low-income individuals, as well as fairness around the choice of products and, consequently, industries to be affected. Other concerns were noted around the threat that materials taxes may pose to the competitiveness of industry, and corresponding risk of leakage as production shifts abroad and job losses. These largely relate to the perceived cost and effectiveness of the proposed policies.

Key actors who are seen to have opposed previous taxes and who may be likely to oppose substantial aspects of the proposed policies include aviation and motor-vehicle industries, groups and lobbies. Other actors who may seek to oppose the proposed measures include the energy intensive industries who stand to be most affected such as the cement, iron, steel and aluminium industries.

Discussion around the perceived threat to the competitiveness of industries in individual Member States may also indirectly stem from a further concern around cultural heritage and a desire to protect traditional industries and jobs in a given area, although this was not a common explicit objection. Based on their use and framing in the discourse, these considerations are all judged to have a likely negative impact on the public acceptability of these three corresponding DYNAMIX policies. Finally, we crucially note a significant lack of discussion around the tax reform benefits or environmental benefits of these types of policies in our assessment of the visible public discourse.

Similarly, the analysis of the discourse around a potential "meat tax" also highlights significant common concerns around fairness (regressivity), cost (affordability; infringement on freedom of choice), motive (revenue use), and effectiveness (competitiveness and border issues).

In contrast, our findings suggest that the two DYNAMIX policies ("Reduced VAT for environmentally advantageous products and services", and "EU-wide feebate schemes for select product categories") which steer away from a focus on "tax increase" and make greater use of "pull" incentives appear to be much less susceptible to the concerns described above. We did not note any significant concerns in the visible public discourse that would be anticipated to negatively affect public acceptability if either of these measures were to be introduced. There appears to be a minor degree of acknowledgement of concerns in the public discourse around additional cost, effectiveness depending on the selection of applicable goods, and fairness based on differential needs for different products (such as a large family needing a large car).

\subsection{Discourse Themes around Alternative (non-Tax) Behaviour Change Policies}

The proposed DYNAMIX policy "Shift from consumption to leisure" explores a combination of measures to reduce working hours such as the encouragement of part-time work and sabbaticals, and longer statutory annual leave. Our analysis for this policy focused on the publicly available discourse surrounding the introduction, implementation and impact of the EU Working Time Directive, first adopted in 1993.

While we found varied support for reduced working time from certain groups (e.g., workers' unions) and in some Member States (e.g., Denmark and France) with discourse framed predominantly around the welfare of workers and the quality of their work, we found a strong and coordinated level of resistance in the public discourse particularly in the UK, and also in Spain and Germany. Key concerns, 
in claims predominantly made by employers and their associations, concentrate on the negative impacts of inflexibility and increased labour costs on economic competitiveness, uncertainty arising from the lack of clarity over how the Directive should be interpreted, and more widely, the impacts of working time restrictions on key public sectors and workers (e.g., doctors, nurses, and fire brigade workers), especially those with on-call time. The impact of concerns has been significant, with the Directive being subject to legal challenges from the UK in 1996, and the inclusion of an opt-out with which to waive the weekly working hours' limit.

With regard to the public acceptability of measures to restrict advertising and marketing, we find a good level of support in the public discourse, particularly for current attempts to restrict misleading and unfair advertising, regulation on advertising related to health (medication, cigarettes), and restrictions on advertising to children. Concerns include appeals to freedom of speech, and the cost to businesses of reduced revenues, which could risk being passed on to individuals through raised product and service charges or potentially through lower wages and job losses.

We find a relatively balanced level of positive and negative public discourse around sharing systems such as shared bicycle and car schemes as proposed in the DYNAMIX policy on "Stimulation of sharing systems". Key concerns appear to focus on cost and effectiveness in terms of the level of public funding needed and available, and fairness in terms of the proportion of the public who are able to access sharing systems relative to who pays for them. We also note broader concerns around personal safety and safety of belongings in the public discourse around, for example, sharing of residential property and home tools and equipment.

We explored the public acceptability of "Local currencies for labour-based services" through an analysis of discourse around the many widespread Local Exchange Trading System (LETS) schemes that already exist in various communities around the world and in the majority of Member States. We find relatively few concerns in our analysis of the visible public discourse; those we did find centre on fairness concerns that LETS schemes might be used by some as a means of avoiding taxation, and freedom of choice concerns should participation in LETS schemes become compulsory.

In our analysis we find strong support in the visible public discourse for efforts to reduce food waste, with particular public support for food waste redistribution programmes such as strong counter-discourse in France in the face of funding cuts to the Fund for European Aid to the Most Deprived (FEAD). The positive discourse appeals to the principles of fairness to the less advantaged associated with food banks, and the "waste-not-want-not" cultural, ethical, environmental and social values as well as efficiency merits of redistributing food waste. The positive discourse is further repeated in events such as the "European Year Against Food Waste", and the first "Day of Prevention of Food Waste" in 2014 in Italy, for example. The main concerns in the public discourse on food waste reduction and redistribution programmes focus on their implementation costs and their effectiveness without appropriate financial support.

\subsection{Discourse Themes for Producer-Focus Policies}

Our analysis suggests that the public discourse around efforts to boost extended producer responsibility and improve product standards in the EU is mixed. These measures appear to be relatively uncontentious throughout most Member States, with positive references in the discourse around take-back schemes touching on social norms and values in Finland and Sweden, for example (e.g., "it's in our blood to make deposits" [70]). However, there are isolated instances of strong negative discourse particularly in the UK and Germany, focusing on concerns around the effectiveness of proposed measures, threats to competitiveness, cost to businesses and consumers, fairness between producers, and freedom of choice. We also found links in the UK discourse between Euroscepticism and negative discourse around higher product standards (e.g., "Now EU targets our kettles, toasters and even lawnmowers" [71]). 


\section{Discussion}

In their current form, seven of the proposed DYNAMIX policies are rated highly contentious. These are: "Green fiscal reform: internalisation of environmental costs", "Green fiscal reform: materials tax", "Circular economy tax trio on extraction, landfill and incineration of virgin materials" and "VAT on meat products" largely due to strong concerns and negative discourse associated with their raising of taxes; "Shift from consumption to leisure", over evidence of strong and continuing opposition to and lack of consensus on the EU Working Time Directive; and "Product standards" and "Extended producer responsibility", because of pockets of strong negative concerns and claims in the absence of sufficient positive discourse to provide counterbalance.

Below we provide some specific recommendations for the design and implementation of these policies which are intended to improve their public acceptability, and hence their overall effectiveness and chance of success. Section 4.1 to Section 4.4 each provide recommendations to civil servants with responsibility for and operational interest in corresponding policy areas. Taken together, the recommendations in these sections are further relevant to individuals and government departments at both national and EU levels with strategic oversight for one or more relevant policy areas (such as national departments e.g., for environment or economy; and relevant EU policy-oriented Directorates-General). Section 4.5 sets out broader reflections and recommendations for policymakers in general as well as other stakeholders and practitioners interested in designing and implementing policies for a transition to sustainability.

\subsection{Recommendations to Improve the Public Acceptability of Green Taxes}

To improve trust and to allay concerns about the fairness and motives of new tax measures in general, we recommend that tax revenues be earmarked transparently for specific issues in line with recent findings $[35,36]$. To maximise public acceptability, it is recommended that information about the destination of revenues be easily accessible and clearly communicated and, where possible, that revenues are recycled back as closely as possible to the affected sector or individuals, for example as financial incentives to support more positive practices (as, for instance, with the UK Aggregates Levy Sustainability Fund [72]).

Border adjustments, with a tax on imports and refunds on exports, may help to address the specific concerns voiced around competitiveness and the possible shift of production activity outside the EU as a result of additional costs to producers from materials taxes.

Finally, we noted a considerable lack of discussion about the benefits of these policies in the public discourse. Efforts to ensure that the benefits associated with these policies are appropriately captured in the public debate may help to improve public acceptability by counter-balancing the salience of concerns, and/or tackling any information deficit.

\subsection{Recommendations to Improve the Public Acceptability of a Meat Tax}

To address and respond to concerns noted in the discourse that a tax on meat could be regressive, disproportionately affecting those on lower incomes, we recommend the careful selection of goods to which the tax will apply, namely those with a high income elasticity of demand (i.e., luxury rather than essential goods) and non-essential for a healthy diet. Choosing goods that are price elastic, and where likely substitutes have a lower environmental impact may also help to mitigate effectiveness concerns.

We recommend prepending the tax with a mix of local and national voluntary initiatives and trials to engage the public with the policy's aim and issues, and any necessary adjustments to its design or implementation.

A more ambitious recommendation to mitigate against perceived effectiveness concerns due to border import issues would be for the measure's implementation to be applied across all EU Member States simultaneously and identically. 
Further recommendations of relevance may be drawn from parallel literature in neighbouring fields such as health including, for example, discussion of the perceived effectiveness and acceptability of taxes on alcohol and sugared products [73-75].

\subsection{Recommendations to Improve the Public Acceptability of a Shift to Greater Leisure Time}

To improve the public acceptability of the DYNAMIX proposals to enable a shift to greater leisure time, we recommend focusing investment in current efforts to revise the Working Time Directive [76], with a particular focus on consulting and negotiating with key actors and prominent voices in the public discourse (such as the ETUC, CEEP, Business Europe, UEAPME) to identify mutually-agreeable fair and safe solutions to key points of concern such as on-call time for key workers.

A promising alternative or complementary approach might be to explore additional policy measures which focus on the purpose of the reduced working hours, for example: increasing provisions for and take-up of leave for specific causes such as parental leave and carer's leave. This may better avoid rebound effects and mitigate the influence of negative lobbying on public discourse by linking the policy to clear and specific social benefits. In a first step, the EU could contribute by comparing effectiveness and economic impacts of different policy options and setting these out in a communication.

\subsection{Recommendations to Improve the Public Acceptability of Product Standards and Extended Producer Responsibility}

The public acceptability of take-back schemes may be enhanced through the addition of incentives (e.g., money-back schemes) and facilitating the easy return of products. A good example includes the return of mobile phones to recycling schemes.

The staggered implementation of product standards across Member States and/or across product types, with transparent feedback of findings at each stage, may improve trust and help to mitigate acceptability issues arising from misconceptions about costs or effectiveness. We recommend prioritising products where the new standards are most likely to generate clear private benefits, to emphasise the business case for producers.

\subsection{Summary Recommendations to Policymakers}

Our concluding recommendations to those designing and implementing policies for a transition to sustainability begin with an emphasis on the importance of public acceptability issues and their relationship with policy success.

The common concerns highlighted in the literature and echoed in our analysis of the public discourse around fourteen policies for sustainability proposed by the DYNAMIX project and echoed in the literature focus primarily on four core overlapping issues: trust, fairness, effectiveness and cost.

Our practical recommendations with respect to improving trust are: to increase transparency around the purpose of measures, reinforcing messages through action, for example by earmarking new tax revenues for purposes related to the corresponding policy objective. Fairness and cost concerns may be partly addressed through intelligent policy design by careful selection of the goods, materials and population sub-groups to be affected, and the measures to be used (such as "carrot" vs. "stick").

Additionally, where any of these core concerns are amplified by mis- (or a lack of) information, experience and public engagement through trials and staggered implementation can help to improve acceptability. As highlighted in the literature and supported by our observations in this study, considerations may be easily swayed by the choice of words, concepts and rhetoric used to frame a given issue; choose these carefully. We also believe that there may be promising potential in the argument for embedding media literacy into national curriculums and its ability to address the so-called information deficit better than the one-way dissemination of information, by empowering individuals and equipping them with the skills to interpret and evaluate sources and claims more critically. 
With respect to the fourth and final issue, effectiveness, our findings point to a strong need to acknowledge the role of key actors such as industry, as their interests are frequently represented in a large proportion of the visible public discourse analysed. Efforts to improve public acceptability should therefore include actively involving and engaging with key actors through consultation and participation in the policy design process to explore mutually agreeable solutions. Policymakers may need to consider making introductory concessions to key actors, for example, in order to support transitions in sectors most affected and make the introduction of proposed policies more acceptable.

We end on two words of warning. First, beware the trade-off between a policy's acceptability and its effectiveness. Public acceptability is not a sufficient condition for policy success; a policy that has been "watered down" to avoid the concerns of all parties may be left without the capacity to achieve its objective, however important it may be. To mitigate against the "watering down" of policy, where possible: (i) provide explicit justification for the choice of instruments, levels and limits using existing policy examples and evidence; (ii) seek cross-party agreement on key policy objectives and policies to minimise the risk that public anxieties about a policy are amplified purely for one-upmanship between competing political parties; and (iii) grow and be prepared to invest political capital - the trust, goodwill, and influence one has with the public and other social, private and political actors; political capital may help to overcome a policy's potentially weakest moments of acceptability, such as on the eve of implementation.

Together these factors can help to create the conditions for desirable windows of opportunity when a policy's acceptability and potential for success are at their highest. The potential for policies once implemented to change behaviour, perception of effectiveness, social norms, trust and therefore the limits of public acceptability highlights the importance of attention to the sequencing of policies for achieving large-scale objectives such as the transition to sustainable resource use. A policy that successfully informs and encourages a positive change in practice may, over time, redefine the limits of public acceptability and the set of policies at the disposal of policymakers. Policymakers should therefore keep in mind the wider context when designing and implementing policies, and consider how these contribute to the broader pathway of change desired.

Our second word of warning is that in addition to such possibilities, the dynamic nature of public acceptability also brings with it its risks. Public acceptance is not final; counter-lobbies can persist, opinions can change, and policies can be undone.

Acknowledgments: This research was conducted as part of a broader program of work under the DYNAMIX project, which has received funding from the European Union FP7 ENV.2010.4.2.3-1 grant agreement No. 308674. We thank Bridget Elliott, Christopher Harvey and our colleagues in the DYNAMIX consortium for their assistance and inputs. All errors are our own.

Author Contributions: Martha Bicket developed the methodology, conducted the background research and search frequency analysis, contributed to the discourse analysis and wrote the bulk of the contribution. Robin Vanner provided intellectual input throughout the work and played a key role in the discourse analysis and results.

Conflicts of Interest: The authors declare no conflict of interest.

\section{Abbreviations}

The following abbreviations are used in this manuscript:

$\begin{array}{ll}\text { AT } & \text { Austria } \\ \text { BE } & \text { Belgium } \\ \text { BG } & \text { Bulgaria } \\ \text { BTU } & \text { British thermal unit } \\ \text { CEEP } & \text { European Centre of Employers and Enterprises providing Public Services } \\ \text { CZ } & \text { Czech Republic } \\ \text { DE } & \text { Germany } \\ \text { DK } & \text { Denmark }\end{array}$


DYNAMIX DYNAmic policy MIXes for absolute decoupling of environmental impact of EU

EL Greece

EPR Extended producer responsibility

ES Spain

ETUC European Trade Union Confederation

EU European Union

FEAD Fund for European Aid to the Most Deprived

FI Finland

FR France

HU Hungary

IE Ireland

IT Italy

LETS Local Exchange Trading System

LT Latvia

LV Lithuania

NL Netherlands

PL Poland

PT Portugal

RO Romania

SE Sweden

SK Slovakia

SL Slovenia

UEAPME European Association of Craft, Small and Medium-sized Enterprises

UK United Kingdom

USA United States of America

VAT Value-added tax

\section{References}

1. Cherry, T.L.; Kallbekken, S.; Kroll, S. The impact of trial runs on the acceptability of environmental taxes: Experimental evidence. Resour. Energy Econ. 2014, 38, 84-95. [CrossRef]

2. Cooper, C.B. Media literacy as a key strategy toward improving public acceptance of climate change science. BioScience 2011, 61, 231-237. [CrossRef]

3. Ford, R.M.; Williams, K.J.H.; Smith, E.L.; Bishop, I.D. Beauty, belief, and trust: Toward a model of psychological processes in public acceptance of forest management. Environ. Behav. 2012. [CrossRef]

4. Lane, M.B.; McDonald, G. Towards a general model of forest management through time: Evidence from Australia, USA, and Canada. Land Use Policy 2002, 19, 193-206. [CrossRef]

5. Steg, L.; Dreijerink, L.; Abrahamse, W. Why are energy policies acceptable and effective? Environ. Behav. 2006, 38, 92-111. [CrossRef]

6. Geels, F.W. The impact of the financial-economic crisis on sustainability transitions: Financial investment, governance and public discourse. Environ. Innov. Soc. Transit. 2013, 6, 67-95. [CrossRef]

7. De Groot, J.I.M.; Schuitema, G. How to make the unpopular popular? Policy characteristics, social norms and the acceptability of environmental policies. Environ. Sci. Policy 2012, 19-20, 100-107. [CrossRef]

8. Drews, S.; van den Bergh, J.C.J.M. What explains public support for climate policies? A review of empirical and experimental studies. Clim. Policy 2015. [CrossRef]

9. Munaretto, S.; Walz, H. Political Feasibility of Climate Policy Instruments in the EU; CECILIA2050 WP4 Deliverable 4.5; Institute for Environmental Studies, VU University Amsterdam: Amsterdam, The Netherlands, 2015; Available online: cecilia2050.eu/publications/264 (accessed on 12 April 2016).

10. Banister, D. The sustainable mobility paradigm. Transp. Policy 2008, 15, 73-80. [CrossRef]

11. Page, B.I.; Shapiro, R.Y. Effects of public opinion on policy. Am. Polit. Sci. Rev. 1983, 77, 175-190. [CrossRef] 
12. Strömbäck, J. The media and their use of opinion polls: Reflecting and shaping public opinion. In Opinion Polls and the Media: Reflecting and Shaping Public Opinion; Palgrave Macmillan: New York, NY, USA, 2012; pp. 1-24.

13. Erlandson, D. Btu Tax Experience: What Happened and Why It Happened. Pace Environ. Law Rev. 1994, 12, 173-184.

14. Dresner, S.; Jackson, T.; Gilbert, N. History and social responses to environmental tax reform in the United Kingdom. Energy Policy 2006, 34, 930-939. [CrossRef]

15. Zvěřinová, I.; Ščasný, M.; Kyselá, E. What Influences Public Acceptance of the Current Policies to Reduce GHG Emissions? In Choosing Efficient Combinations of Policy Instruments for Low-Carbon Development and Innovation to Achieve Europe's 2050 Climate Targets (CECILIA2050); CECILIA2050 WP2 Deliverable 2.5; Charles University Environment Center: Prague, Czech Republic, 2014.

16. Thalmann, P. The public acceptance of green taxes: 2 million voters express their opinion. Public Choice 2004, 119, 179-217. [CrossRef]

17. Gaunt, M.; Rye, T.; Allen, S. Public acceptability of road user charging: the case of Edinburgh and the 2005 referendum. Transp. Rev. 2007, 27, 85-102. [CrossRef]

18. Keramitsoglou, K.M.; Tsagarakis, K.P. Public participation in designing a recycling scheme towards maximum public acceptance. Resour. Conserv. Recycl. 2013, 70, 55-67. [CrossRef]

19. Vaske, J.J.; Absher, J.D.; Bright, A.D. Salient Value Similarity, Social Trust and Attitudes toward Wildland Fire Management Strategies. Hum. Ecol. Rev. 2007, 14, 223-232.

20. Adaman, F.; Karali, N.; Kumbaroğlu, G.; Or, I.; Zenginobuz, U.; Ozkaynak, B. What determines urban households' willingness to pay for $\mathrm{CO}_{2}$ emission reductions in Turkey: A contingent valuation survey. Energy Policy, 2011, 39, 689-698. [CrossRef]

21. Kallbekken, S.; Sælen, H. Public acceptance for environmental taxes: Self-interest, environmental and distributional concerns. Energy Policy 2011, 39, 2966-2973. [CrossRef]

22. Cherry, T.L.; Kallbekken, S.; Kroll, S. The acceptability of efficiency-enhancing environmental taxes, subsidies and regulation: An experimental investigation. Environ. Sci. Policy 2012, 16, 90-96. [CrossRef]

23. Jagers, S.C.; Hammar, H. Environmental taxation for good and for bad: The efficiency and legitimacy of Sweden's carbon tax. Environ. Politics 2009, 18, 218-237. [CrossRef]

24. Schade, J.; Schlag, B. Acceptability of urban transport pricing strategies. Transp. Res. F Traffic Psychol. Behav. 2003, 6, 45-61. [CrossRef]

25. Cacciatore, M.A.; Scheufele, D.A.; Iyengar, S. The End of Framing as We Know It ... and the Future of Media Effects. Mass Commun. Soc. 2016, 19, 7-23. [CrossRef]

26. Reser, J.P.; Bradley, G.L.; Ellul, M.C. Encountering Climate Change:"Seeing" is More than "Believing". Wiley Interdiscip. Rev. Clim. Chang. 2014, 5, 521-537. [CrossRef]

27. Stoutenborough, J.W.; Liu, X.; Vedlitz, A. Trends in public attitudes toward climate change: The influence of the economy and climategate on risk, information, and public policy. Risk Hazards Crisis Public Policy 2014, 5, 22-37. [CrossRef]

28. Scruggs, L.; Benegal, S. Declining public concern about climate change: Can we blame the great recession? Glob. Environ. Chang. 2012, 22, 505-515. [CrossRef]

29. Poortinga, W.; Aoyagi, M.; Pidgeon, N.F. Public perceptions of climate change and energy futures before and after the Fukushima accident: A comparison between Britain and Japan. Energy Policy 2013, 62, 1204-1211. [CrossRef]

30. Ford, R.M.; Williams, K.J.H.; Bishop, I.D.; Hickey, J.E. Effects of information on the social acceptability of alternatives to clearfelling in Australian wet eucalypt forests. Environ. Manag. 2009, 44, 1149-1162. [CrossRef] [PubMed]

31. McQuail, D. Mass Communication Theory; Sage: London, UK, 2005.

32. Vanner, R.; Bicket, M. The role of paradigm analysis in the development of policies for a resource efficient economy. Sustainability 2016. submitted.

33. Stern, P.C.; Dietz, T.; Abel, T.D.; Guagnano, G.A.; Kalof, L. A value-belief-norm theory of support for social movements: The case of environmentalism. Hum. Ecol. Rev. 1999, 6. Article 81.

34. Steg, L.; Dreijerink, L.; Abrahamse, W. Factors influencing the acceptability of energy policies: A test of VBN theory. J. Environ. Psychol. 2005, 25, 415-425. [CrossRef] 
35. Sælen, H.; Kallbekken, S. A choice experiment on fuel taxation and earmarking in Norway. Ecol. Econ. 2011, 70, 2181-2190. [CrossRef]

36. Bristow, A.L.; Wardman, M.; Zanni, A.M.; Chintakayala, P.K. Public acceptability of personal carbon trading and carbon tax. Ecol. Econ. 2010, 69, 1824-1837. [CrossRef]

37. Goldstein, N.; Cialdini, R.B.; Griskevicius, V. A Room with a Viewpoint: Using Social Norms to Motivate Environmental Conservation in Hotels. J. Consum. Res. 2008, 35, 472-482. [CrossRef]

38. Tversky, A.; Kahneman, D. The framing of decisions and the psychology of choice. Science 1981, 211, $453-458$. [CrossRef] [PubMed]

39. Lockwood, M. Does the framing of climate policies make a difference to public support? Evidence from UK marginal constituencies. Clim. Policy 2011, 11, 1097-1112. [CrossRef]

40. Hardisty, D.J.; Johnson, E.J.; Weber, E.U. A dirty word or a dirty world? Attribute framing, political affiliation, and query theory. Psychol. Sci. 2010, 21, 86-92. [CrossRef] [PubMed]

41. Kallbekken, S.; Kroll, S.; Cherry, T.L. Do you not like Pigou, or do you not understand him? Tax aversion and revenue recycling in the lab. J. Environ. Econ. Manag. 2011, 62, 53-64. [CrossRef]

42. Devine-Wright, P. Reconsidering public acceptance of renewable energy technologies: A critical review. In Delivering a Low Carbon Electricity System: Technologies, Economics and Policy; Grubb, M., Jamasb, T., Pollitt, M., Eds.; Cambridge University Press: Cambridge, UK, 2008.

43. Bernauer, T.; Gampfer, R. Effects of civil society involvement on popular legitimacy of global environmental governance. Glob. Environ. Chang. 2013, 23, 439-449. [CrossRef]

44. Lo, A.Y.; Alexander, K.; Proctor, M.; Ryan, A. Reciprocity as deliberative capacity: Lessons from a citizen's deliberation on carbon pricing mechanisms in Australia. Environ. Plan. C Govern. Policy 2013, 31, 444-459. [CrossRef]

45. Stoll-Kleemann, S.; O'Riordan, T.; Jaeger, C.C. The psychology of denial concerning climate mitigation measures: Evidence from Swiss focus groups. Glob. Environ. Chang. 2001, 11, 107-117. [CrossRef]

46. Baumgartner, F.R.; Jones, B.D. Agendas and Instability in American Politics; University of Chicago Press: Chicago, IL, USA, 2010.

47. Kingdon, J.W.; Thurber, J.A. Agendas, Alternatives, and Public Policies; Little Brown: Boston, MA, USA, 1984; Volume 45.

48. Ekvall, T.; Elander, M.; Umpfenbach, K.; Hirschnitz-Garbers, M.; Hudson, C.; Wunder, S.; Nesbit, M.; Keenleyside, C.; Mazza, L.; Russi, D.; et al. Development of DYNAMIX Policy Mixes: Deliverable D4.2. In Prepared in the Context of the FP7-Funded DYNAMIX Project; IVL Swedish Environmental Research Institute: Gothenburg, Sweden, 2015; Available online: dynamix-project.eu/development-dynamix-policy-mixes (accessed on 12 April 2016).

49. Pridmore, A.; Miola, A. Public Acceptability of Sustainable Transport Measures; OECD Publishing: Paris, France, 2011.

50. Steg, L.; Schuitema, G. Behavioural responses to transport pricing: A theoretical analysis. In Threats to the Quality of Urban Life from Car Traffic: Problems, Causes, and Solutions; Emerald Group Publishing Limited: Bingley, UK, 2007; pp. 347-366.

51. Dunlap, R.E.; van Liere, K.D. The "New Environmental Paradigm": A proposed measuring instrument and preliminary results. J. Environ. Educ. 1978, 9, 10-19. [CrossRef]

52. Bornstein, N.; Lanz, B. Voting on the environment: Price or ideology? Evidence from Swiss referendums. Ecol. Econ. 2008, 67, 430-440. [CrossRef]

53. Demski, C.; Poortinga, W.; Pidgeon, N. Exploring public perceptions of energy security risks in the UK. Energy Policy 2014, 66, 369-378. [CrossRef]

54. McCambridge, J.; Witton, J.; Elbourne, D.R. Systematic review of the Hawthorne effect: New concepts are needed to study research participation effects. J. Clin. Epidemiol. 2014, 67, 267-277. [CrossRef] [PubMed]

55. Murphy, J.; Link, M.W.; Childs, J.H.; Tesfaye, C.; Dean, E.; Stern, M.J.; Pasek, J.; Cohen, J.; Callegaro, M.; Harwood, P.G. Social Media in Public Opinion Research: Report of the AAPOR Task Force on Emerging Technologies in Public Opinion Research; American Association for Public Opinion Research: Lenexa, KS, USA, 2014.

56. Weisberg, H.F. The Methodological Strengths and Weaknesses of Survey Research; The SAGE Handbook of Public Opinion Research; SAGE: Thousand Oaks, CA, USA, 2008.

57. Traugott, M.W. The Uses and Misuses of Polls; The SAGE Handbook of Public Opinion Research; SAGE: Thousand Oaks, CA, USA, 2008; p. 232. 
58. Clawson, R.A.; Oxley, Z.M. Public Opinion: Democratic ideals, Democratic Practice; Sage: Thousand Oaks, CA, USA, 2012.

59. Splichal, S. Public Opinion and Opinion Polling: Contradictions and Controversies. In Opinion Polls and the Media: Reflecting and Shaping Public Opinion; Palgrave Macmillan: New York, NY, USA, 2012; pp. $25-46$.

60. Google. Google Trends. Available online: www.google.com/trends/explore (accessed on 2 June 2015).

61. Trevisan, F. Search engines: From social science objects to academic inquiry tools. First Monday 2014. [CrossRef]

62. Wilde, G.R.; Pope, K.L. Worldwide trends in fishing interest indicated by internet search volume. Fish. Manag. Ecol. 2013, 20, 211-222. [CrossRef]

63. Choi, H.; Varian, H. Predicting the present with google trends. Econ. Rec. 2012, 88, 2-9. [CrossRef]

64. Romain, J. Let's not turn our backs on a good samaritan law. The Guardian, 30 January 2015. Available online: www.theguardian.com/commentisfree/2015/jan/30/good-samaritan-law-bureaucracy-health-safety-food -shelter (accessed on 12 April 2016).

65. EUR-Lex. Available online: eur-lex.europa.eu (accessed on 2 June 2015).

66. Statham, P.; Tumber, H. Relating news analysis and public opinion: Applying a communications method as a "tool"to aid interpretation of survey results. Journalism 2013, 14, 737-753. [CrossRef]

67. Koopmans, R.; Statham, P. Political Claims Analysis: Integrating Protest Event and Political Discourse Approaches. Mobil. Int. Q. 1999, 4, 203-221.

68. Stern, M.J.; Bilgen, I.; Dillman, D.A. The state of survey methodology challenges, dilemmas, and new frontiers in the era of the tailored design. Field Methods 2014, 26, 284-301. [CrossRef]

69. Whitmarsh, L. What's in a name? Commonalities and differences in public understanding of "climate change" and "global warming". Public Underst. Sci. 2008, 18, 401-420. [CrossRef]

70. Jackson, F. Time for return of bottle deposits? Raconteur, 5 March 2014. Available online: raconteur.net/ sustainability/time-for-return-of-bottle-deposits (accessed on 12 April 2016).

71. Rao, N. Now EU targets our kettles, toasters and even lawnmowers. Express, 4 September 2014. Available online: www.express.co.uk/news/uk/506749/European-ban-on-household-goods (accessed on 12 April 2016).

72. Daykin, S. ALSF 2008-11 Evaluation. Available online: webarchive.nationalarchives.gov.uk/20130402151656/ http://archive.defra.gov.uk/environment/quality/land/aggregates/documents/alsf-evaluation-full.pdf (accessed on 12 April 2016).

73. Bos, C.; Lans, I.; van Rijnsoever, F.; van Trijp, H. Consumer Acceptance of Population-Level Intervention Strategies for Healthy Food Choices: The Role of Perceived Effectiveness and Perceived Fairness. Nutrients 2015, 7, 7842-7862. [CrossRef] [PubMed]

74. Mazzocchi, M.; Cagnone, S.; Bech-Larsen, T.; Niedźwiedzka, B.; Saba, A.; Shankar, B.; Verbeke, W.; Traill, W.B. What Is the Public Appetite for Healthy Eating Policies? Evidence from a Cross-European Survey. Health Econ. Policy Law 2015, 10, 267-292. [CrossRef] [PubMed]

75. Pechey, R.; Burge, P.; Mentzakis, E.; Suhrcke, M.; Marteau, T.M. Public Acceptability of Population-Level Interventions to Reduce Alcohol Consumption: A Discrete Choice Experiment. Soc. Sci. Med. 2014, 113, 104-109. [CrossRef] [PubMed]

76. European Commission. Public Consultation on the Review of the Working Time Directive Background. Available online: http:/ / ec.europa.eu/ social/BlobServlet?docId=13085\&langId=en (accessed on 1 July 2015).

(C) 2016 by the authors; licensee MDPI, Basel, Switzerland. This article is an open access article distributed under the terms and conditions of the Creative Commons Attribution (CC-BY) license (http://creativecommons.org/licenses/by/4.0/). 